\section{Young kidneys}

Clinical Pediatric Nephrology.

K K Kher, S P Makker.

(Pp 795; \$85.)

New York: McGraw-Hill, 1992.

ISBN 0-07-034543-0.

$M$ uch adult morbidity is initiated in childhood, and renal disease is no exception. If anyone harbours illusions that paediatric nephrology is a small version of adult nephrology this informative, one volume text will put them right.

It is a transatlantic book, well suited to "office" nephrology. For example, there are excellent illustrations of urinary sediment, but with the surprising omission of pus cells and bacteria. Basic diagnostic nephrology is followed by comprehensive accounts of the main specific disorders and complete sections on renal failure, electrolyte disturbances, and neonatal nephrology.

Hypertension and its management are covered fully. The authors point out that relatively little attention has been accorded to the problem in childhood. This in part is due to uncertainty about normal blood pressure. Here is a book that includes the task force charts of age specific centiles, invaluable for reference. The chapter on urinary tract infection includes a detailed account of the features of both host and pathogen which predispose to it. Current controversies such as circumcision and its relation to infection in infant boys, the choice and timing of imaging, and the importance and management of vesicoureteric reflux are also discussed.

This is an impressive book giving a clear, factual, and comprehensive account of the kidney in the growing child, its problems, and their management, with informed discussion of dilemmas and current issues, all well illustrated.-JEAN SMELLIE, senior lecturer in paediatrics, University College and Middlesex School of Medicine

\section{They do it their way}

A Textbook of In Vitro Fertilization and Assisted Reproduction.

Ed P R Brinsden, P A Rainsbury.

(Pp 451; f58.)

Carnforth, Lancashire: Parthenon

ISBN 1-85070-323-X.

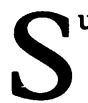
uccessful surgical procedures require two ingredients: a competent team and a good recipe. For an aspiring team wishing to emulate the experts in assisted conception $A$ Textbook of In Vitro Fertilization provides a recipe with a proved track

Illustration by Ian Pillinger for " $E$ " from Alphabet Zoop, a collection of short verses by Dick Smithells, which, their author explains, "were written for fun and are meant to be read for fun. But, just as some modern teachers believe that all education should be fun, some modern parents seem to believe all fun should be educational. So each poem is followed by some tonguein-cheek suggestions as to how it might be turned to educational or moral advantage. They are on no account to be taken seriously." The text for this picture is:

\title{
$\mathrm{A}-$ muse is fun,
}

B-muse is stun,

C-muse fly off at the sound of a gun,

D-muse, a musical higher degree,

$\mathrm{E}$-muse, my animal starting with $\mathrm{E}$.

[An opportunity to explain that seamews are gulls, and that those with doctorates are even less likely to be doctors than bachelors of anything are likely to be unmarried men]

All proceeds from this cheering little volume go to the NSPCC, another good reason for getting your copy. (Obtainable from NSPCC, 10 Woodhouse Square, Leeds LS3 1AD, price £4.99 including postage.)

record. Produced by the editors in response to requests for lecture notes from their training course at Bourne Hall, this is a comprehensive manual of the recipe used there. The result is unashamedly, but understandably, based on the practice of one centre.

Generally it works well. For instance, the instructions for laboratory procedures are clearly detailed and would be easy to follow. The subsequent discussion covers a range of procedures, some of which are indeed based on scientific research; some, however, have been based on little more than "because it works well here." Some data are given to back the methods but, as is commonly found in this subject, there have been few controlled studies.

Protocols for superovulation are also clearly described, although a newcomer to this subject may have difficulty in deciding which protocol to adopt. In contrast, the chapter on the selection of patients is surprisingly brief considering the vital role of selection in any clinical procedure. There is virtually no endocrine assessment of the woman, in contrast with the comprehensive descriptions of investigation and treatment of the man. Psychological evaluation is, yet again, an afterthought in the last chapter. If it is to be an integral part of assisted conception it should surely be considered at the start of treatment.

The fascination of assisted conception techniques comes from the mystery of human reproduction, about which we know so little but which we now have the chance to investigate and understand. Short glimpses are given of, for instance, the factors deter- mining oocyte maturation, early embryo development, and implantation. Understanding these mechanisms will direct the future of assisted conception. It is a pity that a textbook of assisted conception does not give greater prominence to these topics, but the brief references should inspire some readers to explore these aspects further.

As a manual of assisted conception techniques according to the practices of Bourne Hall, the book provides a valuable basis for any clinician wishing to start an assisted conception unit. For established centres it may be of less value, while nevertheless providing an interesting comparison.ALISON MURDOCH, senior lecturer in obstetrics and gynaecology, University of Newcastle upon Tyne

\section{Correction}

\section{Best books on immunology}

A single star crept into the wrong place in A $M$ Denman's article (12 December, p 1513). Clinical Aspects of Immunology 5th edn, by Lachman et al, should have been unstarred as it is not yet published (though a rosette, for a truly outstanding book, is confidently expected)

All titles reviewed here are available from the BMJ Bookshop, PO Box 295, London WC1H 9TE. Prices include postage in the UK and for members of the British Forces Overseas, but overseas customers should add $15 \%$ per item for postage and packing. Payment can be made by cheque in sterling drawn on a UK bank, or by credit card (Mastercard, Visa, or American Express) stating card number, expiry date, and full name. 